\title{
Akne vulgarisli kadın hastalarda isotretinoin, siproteron asetat/etinil estradiol ve kombinasyon tedavilerinin serum androjenik hormon düzeyleri üzerine etkinliklerinin karșılaștırılması
}

\section{Comparison of the efficacy of isotretinoin, cyproterone acetate/ethynil estradiol and combination therapies on serum androgenic hormone levels in females with acne vulgaris}

\author{
Hilal Gökalp, Ahmet Burhan Aksakal* \\ Malatya Devlet Hastanesi, Deri ve Zührevi Hastalıklar Kliniği, Malatya, Türkiye \\ *Gazi Üniversitesi Tıp Fakültesi, Deri ve Zührevi Hastalıklar Ana Bilim Dalı, Ankara, Türkiye
}

Özet

Amaç: Akne vulgaris sebase bezlerin androjenik uyarısıyla karakterize derinin en sık görülen hastalıklarındandır. Bu çalıșmada akne vulgarisli kadın hastalarda isotretinoin, siproteron asetat/etinil estradiol (STA/EE) ve isotretinoin+STA/EE kombinasyon tedavilerinin serum androjenik hormon düzeylerine olan etkilerini inceleyerek isotretinoin tedavisinin antiandrojenik etki mekanizmasını aydınlatmayı amaçladık.

Gereç ve Yöntem: Çalıșmamıza klinik șiddeti Allen-Smith skalasına göre grade 4 ile grade 8 arasında olan ve tedavide sistemik isotretinoin, STA/EE ve isotretinoin+STA/EE kombinasyon tedavisi planlanan 60 kadın hasta dahil edilmiștir. Hastalardan aç karına alınan venöz kan örneklerinde tedavi öncesi, tedavinin 3. ve 6. aylarında androjenik hormon değerleri (androstenedion, luteinizan hormon (LH), follikül stimüle edici hormon (FSH), dehidroepiandrosteron sülfat (DHEAS), serbest ve total testosteron) değerlendirilmiștir. Bulgular: Akne vulgarisli kadın hastalarda isotretinoin tedavisi ile STA/EE tedavisine benzer șekilde serum androstenedion ve serbest testosteron düzeylerinde istatistiksel olarak anlamlı azalma saptanmıștır $(p<0,001)$. Ancak total testosteron ve DHEAS düzeylerinde istatistiksel olarak anlamlı fark gözlenmemiștir ( $p>0,0056)$. LH/FSH oranında ise yine STA/EE tedavisine benzer olarak isotretinoin tedavisi ile istatistiksel olarak anlamlı fark görülememiștir ( $p>0,0056)$.

Sonuç: Akne vulgarisli kadın hastalarda isotretinoinin hormonal bazı etkilerinin de olabileceği düșünülmüștür. Ayrıca akne șiddeti ile androjenik hormon düzeyleri arasında istatistiksel olarak anlamlı korelasyon bulunmamıștır. (Türkderm 2012; 46: 206-9)

Anahtar Kelimeler: Akne vulgaris, isotretinoin, siproteron asetat/etinil estradiol, androjenik hormonlar

\section{Summary}

Background and Design: Acne vulgaris, a multifactorial disease, is one of the most common skin disorders characterized by androgenic stimulation of sebaceous glands. In this study, we aimed to further understand the antiandrogenic effects of isotretinoin, cyproterone acetate/ethynil estradiol (CTA/EE) and isotretinoin+CTA/EE combination treatments on serum androgenic hormone levels.

Materials and Methods: Sixty females with acne vulgaris, who were clinically evaluated as grade 4-8 on Allen-Smith scale, were selected from our patient population for whom isotretinoin, CTA/EE and isotretinoin+CTA/EE combination treatment was planned. Fasting androgenic hormone levels (androstenedion, luteinizing hormone (LH), follicle stimulating hormone (FSH), dehidroepiandrosteron sulfate (DHEAS), and free and total testosterone were evaluated in venous blood before treatment and on the third and the sixth month of the study.

Yazıșma Adresi/Address for Correspondence: Dr. Hilal Gökalp, Malatya Devlet Hastanesi, Deri ve Zührevi Hastalıklar Kliniği, Malatya, Türkiye Tel.: +90 4223240014 Gsm: +90 5325540385 E-posta: hilalgklp@gmail.com Geliş Tarihi/Received: 26.10.2011 Kabul Tarihi/Accepted: xxxx 
Results: Similar to CTA/EE treatment, the decrease in serum androstenedion and free testosterone levels with isotretinoin treatment in females with acne vulgaris were found to be statistically significant $(p<0,001)$. However, there was no significant difference in total testosterone and DHEAS levels ( $p>0.0056)$. There was no statistically significant change in LH/FSH ratio in isotretinoin monotherapy, similar to CTA/EE treatment ( $p>0.0056)$.

Conclusion: We assume that isotretinoin may have an anti-androgenic effect in female patients with acne vulgaris. No statistically significant correlation was found between the severity of acne vulgaris and the androgenic hormone levels. (Turkderm 2012; 46: 206-9)

Key Words: Acne vulgaris, isotretinoin, cyproterone acetate/ethynil estradiol, androgenic hormones

\section{Giriș}

Akne vulgaris 12-24 yaşları arasındaki nüfusun yaklaşık \%85'ini etkileyen en yaygın deri hastalığıdır1,2. Anormal foliküler keratinizasyon, aşırı sebum üretimi, folliküllerde Propionibacterium acnes ( $P$. acnes) kolonizasyonunun artışı ve inflamasyon oluşumu patogenezden sorumlu faktörlerdir ${ }^{3}$. Androjenik hormonların rolü de birçok kez gösterilmiştir4-6. İsotretinoin, akne patogenezindeki major etyolojik faktörlerin tümüne karşı etki gösterebilen tek tedavi ajanıdır7. Son yıllarda androjenik hormonları da etkilediği bildirilmiştir. Ancak bu etkisini hangi mekanizma veya mekanizmalar aracılığı ile gerçekleştirdiği net olarak bilinmemektedir. Bu çalışmada isotretinoin tedavisinin antiandrojenik etkinliğini göstermek amacıyla, isotretinoin, siproteron asetat/etinil estradiol (STA/EE) ve isotretinoin+STA/EE kombinasyon tedavisi verilen akne vulgarisli kadın hastalarda, bu tedavilerin akne kliniğine ve serum androjenik hormon düzeylerine olan etkilerinin incelenmesi amaçlanmıştır.

\section{Yöntem ve Gereçler}

Temmuz 2008-Haziran 2009 tarihleri arasında polikliniklerimize başvuran, 18-40 yaşları arasında, klinik şiddeti Allen-Smith skalasına göre grade 4 ile grade 8 arasında olan 60 kadın hasta çalışmaya dahil edildi. Tedavi öncesinde tam kan sayımı, rutin biyokimya testleri ile lipid profili normal olan hastalara grup 1, 2, 3 olmak üzere sırasıyla isotretinoin, STA/EE ve isotretinoin+STA/EE kombinasyon tedavileri başlandı. İsotretinoin alan gruplarda tedaviye kümülatif isotretinoin dozu minimum $120 \mathrm{mg} / \mathrm{kg}$ olana kadar devam edildi. STA/EE tedavisi ise menstrual siklusun 3. gününden başlanılarak 21 gün süreyle verildi. Yedi günlük ilaçsız dönemden sonra 8. gün tekrar başlanılmak suretiyle toplam 6 siklus uygulandı. Kombinasyon tedavisinde ise isotretinoin ve STA/EE belirtilen şekillerde birlikte verildi. Olgular her ay klinik olarak değerlendirildi.

Sistemik tedavi öncesi ve tedavinin 3-6. ayları sonunda hastalarda androstenedion, total ve serbest testosteron, DHEAS, FSH ve LH düzeyleri çalışıldı. Çalışma öncesinde yerel etik kurul onayı ve tüm olgulardan çalışma konusunda bilgilendirildiklerine dair yazılı onay formu alındı.

\section{İstatistiksel Analiz}

Verilerin analizi SPSS (Statistical Package for Social Science) Windows 11,5 paket programında yapıldı. Sürekli değişkenlerin dağılımının normale yakın olup olmadığı Shapiro Wilk testi ile incelendi. Tanımlayıcı istatistikler ve yaş için ortalama \pm standart sapma şeklinde, hormon düzeyleri ortanca (çeyrekler arası genişlik olarak), akne şiddet düzeyleri ortanca (25.-75.) yüzdelikler şeklinde, nominal değişkenler ise vaka sayısı ve (\%) şeklinde gösterildi. Sonuçlar $p<0,05$ için istatistiksel olarak anlamlı kabul edildi. Olası tüm çoklu karşılaştırmalarda tip । hatayı kontrol altına alabilmek için Bonferroni düzeltmesi yapıldı. Gruplar içerisinde tekrarlayan ölçümler yönünden izlem zamanları arasındaki farkın önemliliği incelenirken Bonferroni düzeltmesine göre $p<0,0056$ için sonuçlar istatistiksel olarak anlamlı kabul edildi.

\section{Bulgular}

Çalışmamıza her üç gruptan da 20'şer kadın hasta dahil edildi. Hastaların yaşları 18 ile 39 arasında değişmekteydi.

Her üç tedavi grubunda da, tedavi öncesine göre tedavinin 6. ayında androstenedion ve serbest testosteron düzeylerinde istatistiksel olarak anlamlı azalma gözlendi ( $p<0,001$ ) (Şekil 1 ve 2). LH/FSH oranında ise her üç tedavi şeklinde de istatistiksel olarak anlamlı bir değişiklik gözlenmedi ( $p>0,0056)$. Total testosteron düzeyi ise sadece kombine tedavi alan grupta istatistiksel olarak anlamlı oranda azaldı $(p<0,001)$. DHEAS düzeyleri açısından yapılan değerlendirmede isotretinoin ve kombine tedavi alan gruplarda istatistiksel olarak anlamlı değişim olmazken $(p>0,0056)$, STA/EE alan grupta istatistiksel olarak anlamlı azalma gözlendi $(p<0,0056)$ (Şekil 3).

Akne şiddet düzeylerinde ise her üç grupta tedavi öncesine göre tedavinin 3. ve 6. aylarında istatistiksel olarak anlamlı azalma gözlendi $(p<0,0056)$ (Şekil 4). Ancak akne şiddeti ile hormon düzeyleri arasında istatistiksel olarak anlamlı korelasyon saptanmadı $(p>0,05)$. Tedavi

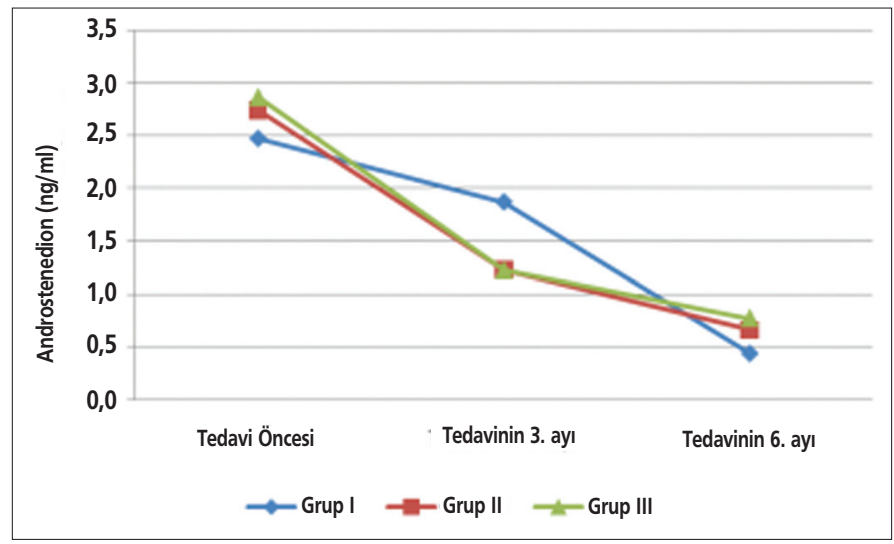

Şekil 1. Gruplara göre tedavi öncesi, tedavinin 3. ve 6. aylarında androstenedion düzeyleri

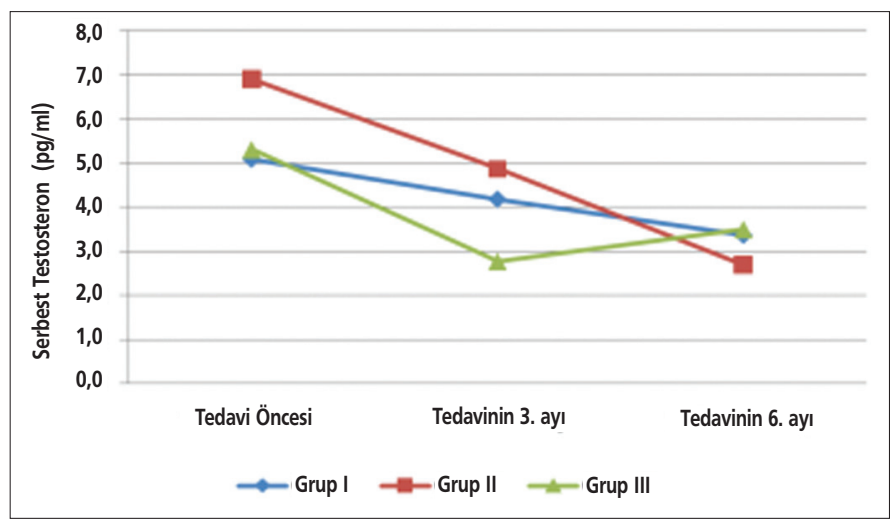

Şekil 2. Gruplara göre tedavi öncesi, tedavinin 3. ve 6. aylarında serbest testosteron düzeyleri 


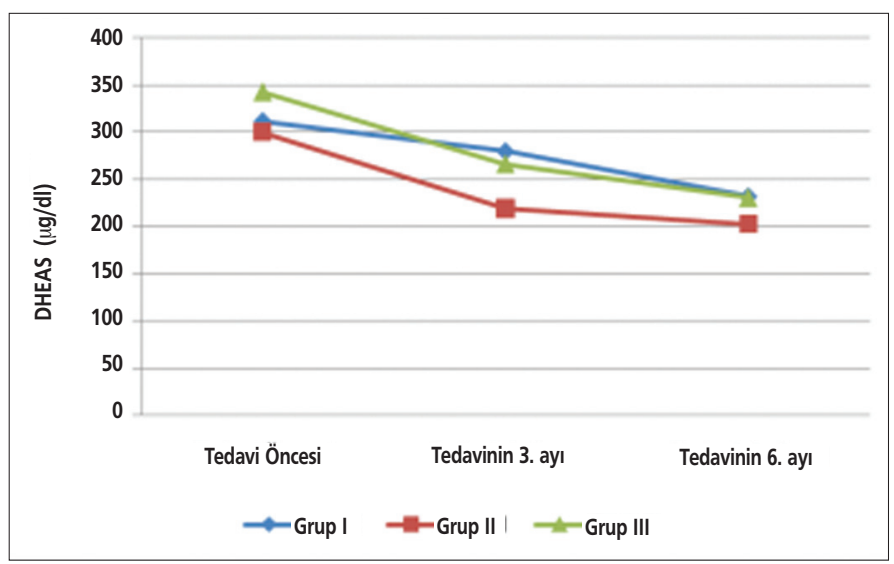

Şekil 3. Gruplara göre tedavi öncesi, tedavinin 3. ve 6. aylarında DHEAS düzeyleri

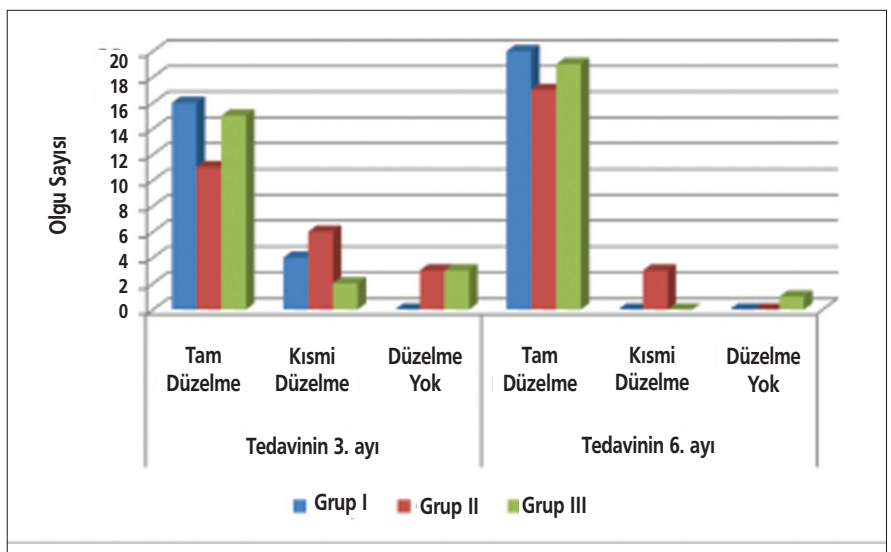

Şekil 4. Tedavinin 3. ve 6. aylarında gruplara göre olguların akne şiddetindeki düzelme yönünden dağılımı

başlangı ında androjenik hormon hakimiyeti olan hastalar ile hormon düzeyleri normal olan hastalar arasında akne şiddeti açısından anlamlı bir fark gösterilemedi $(p>0,05)$.

\section{Tartışma}

İsotretinoinin retinol metabolizmasında yer alan retinol dehidrogenaz4 (RoDH-4) enzimi üzerinden sebase bezlerde androjen metabolizmasını etkilediği ileri sürülmektedir8-10. RoDH-4, $3 \alpha$ androstenediolün ( $3 \alpha$-Adiol) dihidrotestosterona ( $\mathrm{DHT})$, androsteronun ise androstenediona dönüşmesinde rol alarak sebum üretimine katkıda bulunmaktadır. Isotretinoin tedavisi ile oksidatif $3 \alpha$-hidroksisteroid dehidrogenaz ( $3 \alpha$-HSD) aktivitesindeki azalma ve buna bağlı olarak in vitro $\mathrm{DHT}$ ve androstenedion üretiminde baskılanma isotretinoinin RoDH-4'ün oksidatif $3 \alpha$-HSD aktivitesinin güçlü kompetitif inhibitörü olduğunu düşündürmektedir. İlacın sebosupresif etkisinin bu antiandrojenik etkinliğine bağlı olduğu öne sürülmüştür8. Lookingbil ve ark.'nın yaptıkları çalışma ile $3 \alpha$-Adiol serum seviyelerinin düşük bulmaları bu bulguyu desteklemektedir ${ }^{11}$.

$5 \alpha$-redüktaz, sebase bez androjen metabolizmasında anahtar enzimdir12,13. İsotretinoinin $5 \alpha$-redüktaz enzimi üzerine olan etkileri çelişkili sonuçlar vermektedir11,13. İsotretinoinin karaciğerde yapmış olduğu $5 \alpha$-redüktaz inhibisyonu ile hepatik kortisol metabolizmasını ve buna bağlı olarak kortikotropin salınımını azalttığı ve sonuçta da adrenal steroid sentezinin engellendiği öne sürülmüştür ${ }^{11}$. Rademaker ve ark.'nın yaptıkları bir çalışmada isotretinoin tedavisi ile serum testosteron düzeylerinde belirgin düşme olması bu bulguyu desteklemektedir14. Torok ve ark. ise isotretinoin tedavisi ile total testosteron, LH ve FSH düzeylerinde anlamlı bir fark saptamadıklarını bildirmişlerdir15. Marynick ve ark.'ları da benzer şekilde isotretinoin tedavisi ile serum DHEAS, total testosteron, FSH ve LH düzeylerinde istatistiksel olarak anlamlı bir değişiklik bulamamışlardır ${ }^{16}$. Sonuç olarak, isotretinoinin androjenik etkileri üzerine yapılan çalışmalarda tartışmalı sonuçlar alınmıştı $8,11,12,14,17,18$. Ancak genel olarak LH/FSH oranı üzerine bir etkisinin olmaması da dikkat çekicidir15-17.

Çalışmamızda isotretinoin tedavisi ile serum androstenedion ve serbest testosteron düzeylerinde istatistiksel olarak anlamlı bir azalma elde ettik ki bu durum literatürle uyumlu bulundu. Androstenedion düzeylerindeki bu azalma RoDH-4'ün oksidatif $3 \alpha$-HSD aktivitesi üzerine olan olası baskılayıcı etkisi ile açılanabilir. Serbest testosteron düzeylerinde gözlediğimiz azalma ise kortikosteroid metabolizmasında rol alan hepatik $5 \alpha$-redüktaz enzimi üzerine olan baskılayıcı etkisinden kaynaklanabilir. Yine androstenedion düzeylerinde anlamlı azalma ortaya çıkması dolaylı olarak androstenediondan testosteron oluşumunun azalmasına yol açmış olabilir. Çalışmamızda isotretinoin tedavisi ile diğer birçok çalışmaya12,14,16,17 benzer olarak LH/FSH oranında, total testosteron ve DHEAS düzeylerinde istatistiksel olarak anlamlı bir fark gösteremedik. STA/EE tedavisi ile androstenedion, serbest testosteron ve DHEAS düzeylerinde anlamlı bir azalmanın olduğu ve genel olarak da STA/EE tedavisi ile elde ettiğimiz verilerin mevcut çalışmalar ${ }^{19-22}$ ile uyumlu bulunduğu gözlendi. STA/EE tedavisi ile SHBG düzeylerinde ortaya çıkan artış ve ovulasyon inhibisyonu androjenik hormon düzeylerindeki düşmeyi açıklamaktadır.

Akne vulgaris, genç yaş grubunun en sık görülen deri hastalığıdır. Günümüzde akne vulgaris tedavisinde kullanılan en etkili tedavi ajanı olan isotretinoinin, antiandrojenik etkilerine yönelik yapılan çalışmalar yetersiz ve çelişkilidir. İsotretinoin tedavi etkinliğinin STA/EE ile karşılaştııılmış olduğu bu çalışmamızda isotretinoinin androstenedion ve serbest testosteron düzeylerinde yol açtığı düşüşe bağlı olarak antiandrojenik etkiye neden olabileceği düşünülmüştür. Ancak isotretinoinin androjenik hormonlar üzerine olan etkinliğinin değerlendirilmesine yönelik yeni çalışmalara ihtiyaç vardır.

\section{Kaynaklar}

1. Adışen E, Yüksek J, Erdem O, Aksakal FN, Aksakal AB: Expression of human neutrophil proteins in acne vulgaris. I Eur Acad Dermatol Venereol 2010;24:32-7. Epub 2009 Jun 22.

2. Olutunmbi Y, Paley K, English JC 3rd: Adolescent female acne: Etiology and Management. J Pediatr Adolesc Gynecol 2008;21:171-6.

3. Degitz K, Placzek M, Borelli C, Plewig G: Pathophysiology of acne. J Dtsch Dermatol Ges 2007;5:316-23.

4. Zouboulis CC, Chen WC, Thornton MJ, Qin K, Rosenfield R: Sexual Hormones in Human Skin. Horm Metab Res 2007;39:85-95.

5. Lucky AW, Biro FM, Huster GA, et al: Acne vulgaris in premenarchal girls. An early sign of puberty associated with rising levels of dehydroepiandrosterone sulfate levels in boys and girls. Arch Dermatol 1994;130:308-14.

6. Stewart ME, Downing DT, Cook JS, Hansen JR, Strauss JS: Sebaceous gland activity and serum dehydroepiandrosterone sulfate levels in boys and girls. Arch Dermatol 1992;128:1345-8.

7. Ertam I, Alper S, Unal I: Is it necessary to have routine blood tests in patients treated with isotretinoin? J Dermatolog Treat 2006;17:214-6. 
8. Karlsson T, Vahlquist A, Kedishvili N, Törmä H: 13-cis-retinoic acid competitively inhibits 3 alpha-hydroxysteroid oxidation by retinol dehydrogenase RoDH-4: a mechanism for its anti-androgenic effects in sebaceous glands? Biochem Biophys Res Commun 2003;303:273-8.

9. Torma $\mathrm{H}$ : Interaction of isotretinoin with endogenous retinoids. J Am Acad Dermatol 2001;45:143-9.

10. Biswas MG, Russell DW: Expression cloning and characterization of oxidative 17 beta- and 3 alpha-hydroxysteroid dehydrogenases from rat and human prostate. J Biol Chem 1997;272:15959-66.

11. Lookingbill DP, Demers LM, Tigelaar RE, Shalita AR: Effect of isotretinoin on serum levels of precursor and peripherally derived androgens in patients with acne. Arch Dermatol 1988;124:540-3.

12. Matsuoka LY, Wortsman J, Lifrak ET, Parker LN, Mehta RG: Effect of isotretinoin in acne is not mediated by adrenal androgens. J Am Acad Dermatol 1989;20:128-9.

13. Lookingbill DP, Horton R, Demers LM, et al: Tissue production of androgens in women with acne. J Am Acad Dermatol 1985;12:481-7.

14. Rademaker $M$, Wallace $M$, Cunliffe $W$, Simpson NB: Isotretinoin treatment alters steroid metabolism in women with acne. Br J Dermatol 1991;124:361-4.

15. Torok L, Kadar L, Kasa M: Spermatological and endocrinological examinations connected with isotretinoin treatment. Andrologia 1987;19:629-33.
16. Marynick SP, McCaffree DM, Zachariah NY: Evaluation of the influence of isotretinoin and dexamethasone on adrenal, pituitary-gonadal function in men with cyctic acne. N Engl J Med 1983;308:981-6.

17. Palatsi R, Ruokonen A, Oikarinen A: Isotretinoin, tetracycline and circulating hormones in acne. Acta Derm Venereol 1997;77:394-6.

18. Gomez EC, Moskowitz RJ: Effect of 13-cis-retinoic acid on the hamster flank organ. J Invest Dermatol 1980;74:392-7.

19. Carlborg L: Cyproterone acetate versus levonorgestrel combined with ethinyl estradiol in the treatment of acne. Results of a multicenter study. Acta Obstet Gynecol Scand Suppl 1986;134:29-32.

20. Lucky AW, Henderson TA, Olson WH, et al: Effectiveness of norgestimate and ethinyl estradiol in treating moderate acne vulgaris. I Am Acad Dermatol 1997;37:746-54.

21. De Leo V, Morgante G, Piomboni P, et al: Evaluation of effects of an oral contraceptive containing ethinylestradiol combined with drospirenone on adrenal steroidogenesis in hyperandrogenic women with polycystic ovary syndrome. Fertil Steril 2007;88:113-7. Epub 2007 Apr 6.

22. Fugere P, Percival-Smith RK, Lussier-Cacan S, Davignon J, Farquhar D: Cyproterone acetate/ethinyl estradiol in the treatment of acne. A comparative dose-response study of the estrogen component. Contraception 1990;42:225-34. 